\title{
The Perception of Coastal Communities toward the Relationship of Social-Entrepreneurship, Socio-Economic and Quality of Life
}

\author{
Muhammad Abi Sofian Abdul Halim ${ }^{\star}$ \\ Mohd Shaladdin Muda1 \\ Wan Abd Aziz Wan Mohd Amin² \\ Ahmad Munir Mohd Salleh ${ }^{1}$ \\ 1 Universiti Malaysia Terengganu \\ *Email: ppppm@umt.edu.my \\ 2Universiti Sultan Zainal Abidin
}

Doi:10.5901/mjss.2015.v6n4s2p667

\begin{abstract}
This study presents an insight perception of coastal entrepreneurs with regards to the business opportunities that have been accommodated by government to increase their level of income, employment opportunity and quality of life. The aim of the study is to identify the factors of social-entrepreneurship in developing the socio-economic as well as to change the coastal communities' social life in Terengganu. Simple random sampling was used to distribute 300 questionnaires among coastal entrepreneurs in east coast Malaysia. However, there are only 266 set of questionnaires were replied. The results indicate that factors of cooperation, non-profit and welfare in social-entrepreneurship are contributed to the quality of life. Meanwhile, the factor of socio-economic becomes important mediator in association of welfare and quality of life. In summary, the study will help the state governments in east-coast Malaysia to identify the factors and items that important to coastal entrepreneurs in developing their business performance as well as contributing to the changing of their social-life.
\end{abstract}

Keywords: social entrepreneurship; coastal-communities; quality of life; fisheries; aquaculture; seafood product processing;

\section{Introduction}

In Malaysia, the urbanization and industrialization process is taking place and directly contributed negative affect to the number of rural entrepreneurs who are operated their business in east coast Malaysia. Consequence, most of rural coastal residents migrated to urban areas and significantly contributed to the reduction of number of rural entrepreneurs in rural economic activity, especially those enterprises in micro, small and medium scale. Instead of that, the expansions of high-technology industry in coastal areas have created job opportunities amongst rural entrepreneurs and significantly contributed to the reduction of small enterprises operated. Furthermore, these issue also arises caused of dissatisfaction of coastal entrepreneurs toward the business opportunities that facilitated by government. Currently, government launched several policies which regarding to the entrepreneurship development and took rigorous action in implementing several programs that capable to eradicate poverty, created employment and upgrading the level of income as well as changing the social-life in rural areas. Nevertheless, only a few numbers of coastal entrepreneurs in east-coast Malaysia who are aware these policies and met the government visions. Some scholars, policy-makers and industrial practitioners have discussed several studies that regarding to the issue of entrepreneurship as well as mechanism in constructing the coastal communities in east-coast Malaysia. A particularly relevant stream of theory to explain the coastal entrepreneurs' issues is the theory of social entrepreneurship. The study incorporated the theory of social entrepreneurship in order to construct the practical model as well as reference for coastal entrepreneurs who involved in business of fisheries, aquaculture, seafood product processing, coastal tourism, crafts and others enterprises in coastal areas of east-coast Malaysia.

\section{Background of Study}

Previous research shows the study of coastal communities that has been done by a numbers of scholars, academicians 
and politicians in several ways and perspectives for different objectives. However, there appears to be a lack of paradigms' uniformity which particularly in the field of micro and small enterprise. It can be said that not many scholars or academicians are really keen to study the important of social entrepreneurship in developing coastal communities in eastcoast Malaysia, in the context of fisheries, aquaculture, seafood product processing, coastal tourism, crafts and others enterprises. Therefore, the study of social entrepreneurship in coastal communities is important as well as a unique set of processes that may help to explain the social-entrepreneurship as a critical factor in changing quality of life in east-coast Malaysia. Malaysian government has taken responsibility to develop the micro, small and medium scale business in several sectors and industries in the east-coastal areas of Malaysia such as fishery, agriculture, coastal tourism, crafts, food processing and other operated business. Nowadays, the government has developed and constructed a numbers of mega project in supporting the coastal comunities such as the fishery port by Fisheries Development Authority of Malaysia or known as Lembaga Kemajuan Ikan Malaysia (LKIM), the development of coastal activities that grounded from aquaculture product and coastal tourism by Malaysia Tourism Promotion Board (MTPB), and also the fisheries production process. Additionally, a number of government agencies that related to the entrepreneurial development have attempted to conduct the entrepreneurial training service, assist the business financial, design and develop the business facilities, and create market opportunities for entrepreneurs who planned to expand their market segment. A numbers of higher learning institiutions in the east-coast of Malaysia such as Universiti Teknologi MARA, Universiti Malaysia Terengganu, Universiti Malaysia Kelantan, Universiti Sultan Zainal Abidin and Universiti Malaysia Pahang are collaborating with entrepreneurship agencies as well as planned to transform the coastal enterprises into successful entrepreneurs.

\section{East Coast Economic Region}

In 2007, Malaysia government has launched the East Coast Economic Region (ECER) which is considered as a master plan in developing the economic region in Kelantan, Terengganu, Pahang and the district of Mersing in the north state of Johor. The main objective of the plan is to eradicate poverty, raise incomes and improve income distribution in a sustainable manner for coastal communities in east-coast Malaysia (East Coast Economic Region, 2012). ECER also emphasized the transformation of natural resources, distinctive culture and heritage into one that is dynamic and competitive in light of greater regional and global competition and economic liberalization. Generally, the ECER intended to create income growth, return on land investment, boost in tourism and agriculture development for coastal residents in east Malaysia. Therefore, the concept of social entrepreneurship becomes crucial in developing the human capital and human social to rural coastal entrepreneurs as well as to become educated and innovative persons. According to Nor Hayati Sa'at (2011), human capital (skill, knowledge and education) and human social (norm, value and believe) are the factors that are contributed to the development of social mobility. A numbers of scholars have also discussed the factors such as business cooperation, non-profit concerning, volunteerism, welfare and social work which are crucial in constructing the concept of social-entrepreneurship (Yunus, 2011; Zakaria, 2011; Yunus, 2009; Brooks, 2008; Weerawardena \& Mort, 2006; Sarif et al., 2013; Mair \& Marti, 2006; Zahra et al., 2009; Bygrave \& Hofer, 1991). Issue arise in terms of how many coastal residents in the east-coast of Malaysia who are concern with the roles of socialentrepreneurship which able to develop their social-economic, create business opportunities, upgrade their income, eradicate the poverty and improve their quality of life. Therefore, the study attempts to construct the principles of social entrepreneurship as a mechanism in developing the socio-economic among coastal communities in Terengganu as well as east-coast Malaysia in the context of creating the business opportunities, upgrading the income, eradicating the poverty and structuring the quality of life as well as changing the social life.

\section{Coastal Communities in East-Coast Malaysia}

Since last decade, the modernizations of technology and new economy approach in Malaysia have been assimilated Malaysian population into a new culture of social life. The changing of culture also directly created a new paradigm among people in rural areas to find job opportunities in high scale sectors and industries in urban areas. Scholars and policy-makers have argued that the migration of rural residents into urban areas significantly contributing to the declining of rural residents in a rural economic. Generally, a better job opportunities in industrial and urban areas is significantly affected rural communities to make their decision to move into urban areas (Othman, 2002), particularly among coastal communities who are desire to grab job opportunities in the hope to change their social-lifestyle (Nawang et al., 2009). This is due to the benefit of living in urban areas which able to enhance society social life such as housing, shopping, transportation, healthcare, education, government, religious, public safety and recreation (Rostam, K., 2005). However, 
Sirgy et al. (2008) have argued that the concept of social life is not totally depending in the context of new social development that discovered in urban areas, but the concept of social development also occurred in rural areas which can be achieved by constructing a valuable socio-economic concept among rural people. The concept is able to create and upgrades the sources of income, provide a better education and involve in any activities that capable to increase the quality of life.

Currently, Malaysia government has been implemented several numbers of policies related to the economy that support the rural residents in a context of poverty eradication, job opportunities, business opportunities and also upgrading the family and household income (Mat et al., 2003). In addition, Hamzah et al. (2010) have mentioned that the development of people in a concept of social life is not totally depending on the constructing of material perception. However, the factors of spiritual and emotion are also become crucial as underlying variable as well as to develop the human characteristic. Therefore, most of scholars and academicians in social science have agreed that the factor of modernization and urbanization is not only discussing the factor that capable to change social-life. However, the structural planning of human development such as social-entrepreneurship becomes crucial in developing the socialeconomic as well as capable to change the quality of life.

Similarly, these particular issues have arisen among coastal communities in Terengganu who are living at coastal areas such as Kuala Besut, Tembila, Penarek, Merang, Merchang, Kuala Dungun, Kemasek, Kijal, Chukai and Kuala Kemaman as shows in Table 1. Although government sectors have implemented several policies such New Economic Policy, National Development Policy and Vision 2020 in restructuring the coastal communities' social-economic, some of coastal communities are ignorant and dissatisfied with these opportunities. This is supported by Nawang et al. (2009) which have mentioned that most of rural youth who are living in Kuala Besut, Terengganu are not really interested to grab business opportunities as their profession. Idris (2001) also discovered that most of youngsters in coastal areas are uninterested to involve in fisheries or others marine industries as compared to work in variety of sectors in urban areas. In fact, some of them are not interested to develop their business career in the field of coastal entrepreneurship (Nawang et al., 2009).

In summary, the movement of coastal communities from rural areas to urban industrial areas will significantly affected to the deficient of coastal communities involvement in entrepreneurship in a sector of fishery, aquaculture, fish processing plant and coastal tourism (Zakaria, 2011). Although the development of high-technology industry in coastal areas such as Dungun, Paka, Kerteh, Kemasek, Kijal, Chukai, Gebeng, Semambu and Pekan have created business opportunities, it significantly shows the reduction of numbers of coastal residents involved in entrepreneurship (Rostam, 2005). Additionally, the development of high-technology industry in Terengganu coastal areas have provided great opportunities to the medium and big scales companies that are owned by foreign business as compared to the local communities who just operated their enterprises in a micro and small scale (Ariff et al., 2012). These scenarios turned into a business threats to local entrepreneurs. Rostam (2005) indicated that there are $87 \%$ of Malay communities in Kemaman which operated in small scale business and informal as compared to the others foreign company that successfully created their medium and big scale of business.

Table 1. The Business Activities of Coastal Communities in East-Coast Malaysia (Halim et al., 2014)

\begin{tabular}{|c|c|c|}
\hline State & Coastal Areas & Coastal Business Activities \\
\hline Terengganu & $\begin{array}{ll}\text { - } & \text { Kuala Besut } \\
\text { - } & \text { Tembila } \\
\text { - } & \text { Penarek } \\
\text { - } & \text { Merang } \\
\text { - } & \text { Kuala Terengganu } \\
\text { - } & \text { Chendering } \\
\text { - } & \text { Marang } \\
\text { - } & \text { Merchang } \\
\text { - } & \text { Kuala Dungun } \\
\text { - } & \text { Paka } \\
\text { - } & \text { Kerteh } \\
\text { - } & \text { Kemasek } \\
\text { - } & \text { Kijal } \\
\text { - } & \text { Chukai } \\
\text { - } & \text { Kuala Kemaman }\end{array}$ & $\begin{array}{l}\text { Fisheries, fishery processing, tourism } \\
\text { Fisheries } \\
\text { Fisheries, fishery processing } \\
\text { Fisheries, fishery processing, tourism } \\
\text { Fisheries, fishery processing, tourism, craft } \\
\text { Fisheries, fishery processing, tourism } \\
\text { Fisheries, fishery processing, tourism, craft } \\
\text { Fisheries, fishery processing } \\
\text { Fisheries, fishery processing, tourism } \\
\text { Fisheries, fishery processing, tourism } \\
\text { High-technology, fisheries, fishery processing, tourism } \\
\text { High-technology, fisheries, fishery processing } \\
\text { High-technology, fisheries, fishery processing } \\
\text { High-technology, fisheries, fishery processing } \\
\text { High-technology, fisheries, fishery processing, tourism, craft } \\
\text { High-technology, fisheries, fishery processing } \\
\text { High-technology, fisheries, fishery processing, tourism }\end{array}$ \\
\hline
\end{tabular}


Hence, the collaboration and cooperation among small and medium business scales' coastal entrepreneurs within a concept of 'umbrella' is strongly recommended. Social entrepreneurship approaches towards development of the coastal communities also vital in order to nurture the culture of business cooperation, non-profit development of the business channel, volunteerism, welfare and balance social work as well as to achieve the 'umbrella'. This has been supported by Alvord et al. (2004), Barendsen and Gardner (2004), Thompson (2002), Schumpeter (2009) and Zakaria (2011) that all of these factors significantly contributed to the development of communities in a context of social, economy, culture, and business.

\section{Literature Review}

According to Brooks (2008), many scholars have discussed the term of social entrepreneurship with regards to the cooperation of entrepreneurs in developing their individual business, the concerning of entrepreneurs regarding the nonprofit business, the emphasizing of volunteerism and welfare concept in a business, and to create the business is part of the social work. In fact, the field of social entrepreneurship research has been gaining impetus in recent years (Young, 1986; Light, 2005; Alvord et al., 2004; Barendsen \& Gardner, 2004; Thompson, 2002; Schumpeter, 2009). However, there appears to be less social entrepreneurship research on small and medium enterprises (SMEs) in coastal communities. It is surprising as a large number of small enterprises are found operated in coastal areas, especially in east-coast Malaysia (Nawang, 2009; Samsudin et al., 2011; Rostam, 2005). Table 2 shows a numbers of indicators in social entrepreneurship that described by previous studied.

Table 2. The Indicators in Social-Entrepreneurship (Halim et al., 2014)

\begin{tabular}{|c|c|c|}
\hline Indicators & Description & Authors \\
\hline Business cooperation & $\begin{array}{l}\text { - Giving loan to the poor communities in starting their business. } \\
\text { - Abolish the character of selfish. } \\
\text { - } \quad \text { Encompassing social venture. } \\
\text { - } \text { the community involve together. } \\
\text { - An enterprise that uses free market to address a pressing social problem. }\end{array}$ & $\begin{array}{l}\text { Zakaria, } 2011 \\
\text { Yunus, } 2009\end{array}$ \\
\hline Non-profit concerning & $\begin{array}{l}\text { - } \quad \text { More on social mission than business mission. } \\
\text { - } \quad \text { Social problems or needs that are unmet by private markets or government. } \\
\text { - Engages with the financial social returns. }\end{array}$ & Brooks, 2008 \\
\hline Volunteerism & $\begin{array}{l}\text { - } \quad \text { Provide services to the society for free. } \\
\text { - } \text { manage the venture. } \\
\text { - } \quad \text { Gotivated primarily by social benefit. } \\
\text { - Grab social benefit than business profit. }\end{array}$ & $\begin{array}{l}\text { Weerawardena, } 2006 \\
\text { Brooks, } 2008 \\
\text { Sarif et al., } 2013\end{array}$ \\
\hline Welfare and social work & $\begin{array}{l}\text { - Helping poor communities through entrepreneurship activities. } \\
\text { - To optimize the value for social ends. } \\
\text { - } \quad \text { In raise the income of impoverished communities. } \\
\text { - Identify the problems to society. } \\
\text { - Extensively works on the societal development. }\end{array}$ & $\begin{array}{l}\text { Yunus, } 2011 \\
\text { Mair and Marti, } 2006 \\
\text { Zakaria, } 2011 \\
\text { Zahra et al., } 2009 \\
\text { Bygrave and Hofer, } 1991\end{array}$ \\
\hline
\end{tabular}

\section{Problem Stetements}

There are several factors which highlighted the problems that are faced by coastal entrepreneurs in east-coast Malaysia. Firstly, the development of industrial areas have affected to the rural coastal residents which interested to find job opportunities in urban as well as capable to obtain a benefit to contributing their quality of life. Therefore, the movement of rural coastal residents into urban areas significantly contributing to the declining of rural residents in coastal entrepreneurship, especially those already manages their enterprises in micro, small and medium scale. It can be said that some of the rural coastal residents have never thinks that entrepreneurship is able to change their social lifestyle.

Furthermore, some of coastal communities are ignorant and dissatisfied with the business opportunities that accommodated by government in coastal areas. In fact, some of coastal communities did not believe the capability of government to implement the entrepreneurial development programs. Furthermore, the developments of high-technology industry in coastal areas have created a modern social-life among coastal communities which are declining the concepct of Malay social life. It is also affected the culture of individualistic among coastal entrepreneurs in east-coast Malaysia. 
Additionally, the concept of individualistic that has been adopted by the coastal entrepreneurs has declining the approach of social-entrepreneurhip in factors of cooperation in business, volunteerism, welfare and social activities.

Some of coastal communities are also assume that to become entrepreneurs, they will face several critical problems such as how to grab the business opportunities, competitive, controlling the financial and organization mangeriable. In general, they have never thinks that the concept of social-entrepreneurship is capable to help them to achieve a good business management. It can be said that most of them are not really practicing the concept in their business. In summary, the social-entrepreneurship concept emphasizing the factors that contributed to the changing of social-life in a context of higher income, education and quality of life.

\section{Research Questions}

Previously, Malaysian government has launched a numbers of programs and projects in public policies for micro, small and medium entrepreneurs which operated their business somewhere in coastal areas in east-coast Malaysia. The objectives of these programs are to create a business growth for coastal communities and improve their quality of life. In addition, most of government programs are design to create the cooperation among the coastal entrepreneurs as well as the concept of social-entrepreneurship. However, how many of coastal communities are aware with the concept of socialentrepreneurship? Additionally, Malaysia government has also planned and developed a numbers of coastal projects in fishery, agriculture, coastal tourism, crafts, fishery-products processing and other business programs in coastal areas. However, how many of coastal entrepreneurs are satisfied with the implementation of government policies that are related to the social entrepreneurial development?

\section{Research Objectives}

The main objective of the study is to analysis the effectiveness of social-entrepreneurship that capable to develop the social-economy and directly changing the quality of life among coastal communities in east-cost Malaysia. As well as to consolidate of these objectives, there are 2 minor objectives of these studies have been constructed which are:

- To identify the variables of social-entrepreneurship which are practically capable to construct the coastal communities as well as changing their quality of life

- To analyses the effectiveness of socio-economic in contributing the role of socio entrepreneurship in changing the quality of life.

\section{Hypothesis}

As well as the study is to measure the relationship between the variables in a social-entrepreneurship (e.g: business cooperation, non-profit concerning, volunteerism, welfare and social work), social economic and quality of life, 9 hypotheses have been identified in order to determine significant relationships between variables. These 9 hypotheses or testable statements have been formulated based on research objectives and questions such as:

H1: The practice of cooperation in social-entrepreneurship will positively contribute to the quality of life.

$\mathrm{H} 2$ : The practice of non-profit concerning in social-entrepreneurship will positively contribute to the quality of life.

H3: The practice of volunteerism in social-entrepreneurship will positively contribute to the quality of life.

H4: The practice of social work in social-entrepreneurship will positively contribute to the quality of life.

H5: The practice of social economic will positively contribute to the quality of life.

H6: The practice of cooperation in social-entrepreneurship will positively contribute to the social economic. economic.

$\mathrm{H7}$ : The practice of non-profit concerning in social-entrepreneurship will positively contribute to the social

H8: The practice of volunteerism in social-entrepreneurship will positively contribute to the social economic.

H9: The practice of social work in social-entrepreneurship will positively contribute to the social economic.

\section{Methodology}

\subsection{Population and sampling}

In order to construct the social-entrepreneurship model as mechanism in developing the coastal communities, the population of the research is only for the coastal entrepreneurs who are operated their business in Terengganu as well as 
east-coast Malaysia. In total, there are 15 places were identified as coastal areas in Terengganu that are actively manage the activity of socio-entrepreneurship. In term of sampling, the study adopted the simple random sampling. There are 300 questionnaires were distributed to Terengganu's coastal entrepreneurs who operated their business from Kuala Besut to Kuala Kemaman, and 20 questionnaires were distributed for each place of coastal areas. However, only 226 of questionnaires were accepted as described in Table 3.

\subsection{Instruments}

The study involved data collection from coastal entrepreneurs who are operated their business in coastal areas. A selfadministrated survey was conducted through constructed of the instrument in the study. In general, the instrument consist of 6 items to describe the profile of respondents and 10 items for each factor in a section of business cooperation, nonprofit concerning, volunteerism, welfare and social work, social economy, socio-economic and quality of life.

Table 3. The Numbers of Respondents According to Places in East-Coast Malaysia

\begin{tabular}{|lccc|}
\hline Coastal Areas & & Questionnaires Distributed & Replied \\
\hline North Terengganu & Kuala Besut & 20 & 18 \\
& Tembila & 20 & 17 \\
& Penarek & 20 & 17 \\
East Terengganu & Merang & 20 & 19 \\
& Kuala Terengganu & 20 & 20 \\
& Chendering & 20 & 20 \\
& Marang & 20 & 18 \\
South Terengganu & Merchang & 20 & 18 \\
& Kuala Dungun & 20 & 20 \\
& Paka & 20 & 16 \\
& Kerteh & 20 & 17 \\
& Kemasek & 20 & 12 \\
& Kijal & 20 & 15 \\
Total & Chukai & 20 & 19 \\
& Kuala Kemaman & 20 & 20 \\
& & 300 & 266 \\
\hline
\end{tabular}

\subsection{Measurement}

Furthermore, data is analyzed by using Social Package for Social Sciences (SPSS) to measure the relationship between the factors of social-entrepreneurship (e.g: business cooperation, non-profit concerning, volunteerism and welfare), socioeconomic and quality of life. Through univariate statistics, the data were analyzed to check the distributions of frequencies and to detect the possible errors that occurred during data entry. The research also uses statistical techniques of multiple regressions in order to identify the path coefficients and to measure the relationship of standardized regression coefficients or beta value. As well as assumed that path-analysis is an extension of the regression analysis (Wright, 1960), the analysis was conducted to examine complex and multidimensional relationships among variables. Researcher had evaluate the relationship of social entrepreneurship, social economy and quality of life on 5 point Likert scale $(1=$ Strongly disagree; $2=$ Disagree; $3=$ Agree/Disagree; $4=$ Agree; $5=$ Strongly agree) . Therefore, there are 3 sections of data analysis which including descriptive study on respondents' profile, multiple regression on association between variables and path-analysis.

\section{Analysis and Finding}

\subsection{Profile of respondents}

In term of gender, Table 4 reveals that 236 from 266 persons (88.7\%) were male and only $30(11.37 \%)$ is female. In a context of education, the result also illustrates that some selected respondents were among school level (53\%), followed by certificate (40.6\%), diploma (4.5\%), degree (0.8\%) and others (1.1\%). 
Table 4. The Profile of Respondents

\begin{tabular}{|cccccc|}
\hline Items & Frequency & $\%$ & Items & Frequency & $\%$ \\
\hline Gender & & & Types of business & & \\
Male & 236 & 88.7 & Fishery & 78 & 29.3 \\
Female & 30 & 11.37 & Aquaculture & 12 & 4.5 \\
Age & & & Sea product processing & 74 & 27.8 \\
Below 20 years old & 2 & 8 & Coastal tourism & 32 & 12 \\
20-29 years & 32 & 12.0 & Agriculture & 39 & 14.7 \\
30-39 years & 86 & 32.3 & Crafts & 31 & 11.6 \\
40-49 years & 87 & 32.7 & Level of education & & \\
Above 50 year & 59 & 22.2 & School & 141 & 53.0 \\
Business activity & & & Certificate & 108 & 40.6 \\
Producer & 190 & 71.4 & Diploma & 12 & 4.5 \\
Wholesaler & 16 & 6.0 & Degree & 3 & 1.1 \\
Retailer & 60 & 22.6 & Others & & \\
Form of business & & & & & \\
Single ownership & 215 & 80.8 & & & \\
Partnership & 38 & 14.3 & & & \\
Private limited (Sdn. Bhd.) & 13 & 4.9 & & & \\
\hline
\end{tabular}

Generally, $215(80.5 \%)$ of coastal entrepreneurs form their business in sole proprietorship or single ownership, followed by 38 as partnership (14.3\%) and only 13 of costal entrepreneurs (4.9\%) were develop as private limited. As well as to study the profile of business among coastal communities in Terengganu, most of them were involved in fishery (29.3\%), sea product processing (27.8\%), agriculture (14.7\%), coastal tourism (12.0\%), crafts (11.6\%) and aquaculture (4.6\%). In term of business activity, the results indicated that most of them have set up their business as producer (71.4\%), wholesaler (6.0\%) and retailer (22.6\%).

\subsection{Reliability}

In Table 5, the reliability coefficient indicates that there was a high level of consistency in the responses given by the respondents. As stated by Nunnally and Bernstein (1994), the result of reliability coefficient is 0.7 and above levels considered that more than accepted for most behavior science applications.

Table 5. The Result of Reliability Coefficient

\begin{tabular}{llcc}
\hline & Variables & N of Items & Cronbach's Alpha \\
\hline Independent variable & Business cooperation & 10 & 0.931 \\
& Non-profit concerning & 10 & 0.906 \\
& Volunteerism & 10 & 0.894 \\
& Welfare & 10 & 0.925 \\
Intermediary variable & Social economic & 10 & 0.932 \\
Dependent variable & Quality of life & 10 & 0.931 \\
\hline
\end{tabular}

The results of the reliability become prominent and it is related to the validity concept. It is to prove the instrument that be used is consistent, stable and predictable.

\subsection{Path-analysis}

As well as assumed that path-analysis is an extension of the regression analysis (Wright, 1960), the analysis was conducted to examine complex and multidimensional relationships among variables. The significance results of multiple regressions attempt to illustrate the interrelationship of cooperation, volunteerism, social work and welfare (independent variables) with the social economy (intermediary variable) and quality of life (dependent variable). The analysis was used a path coefficient which applied the standard regressions coefficient to show the direct and indirect effect of independent variables on a dependent variable in the path-model.

In order to test the hypothesis of the study, it has utilized a multiple regression analysis to tests the significance 
relationship between variables. Fundamentally, the study of path analysis will involve 2 runs of simulation by using SPSS. Firstly is to identify the significance relationship of variables, and secondly is to identify the strength of the relationship.

\subsection{Relationship of social entrepreneurship and quality of life (first layer)}

In order to identify the significance relation between variables in a first layer, there are 4 factors of socialentrepreneurship that were analyzed to indicate the significance relationship to quality of life such as cooperation, nonprofit concerning, volunteerism and welfare as well as in hypothesis $\mathrm{H} 1, \mathrm{H} 2, \mathrm{H} 3$ and $\mathrm{H} 4$. In order to study the path analysis, social economic become as intermediary variable in testing the H5. The results indicate that are 3 out of 4 variables are significance to the dependence variable which are $\mathrm{H} 1(p=0.005), \mathrm{H} 2(p=0.001), \mathrm{H} 4(p=0.000)$ and $\mathrm{H} 5(\mathrm{p}$ $=0.000$ ), where only H3 (relationship between volunteerism and quality of life) is not significance $(p=0.100)$. Therefore, the factor of volunteerism is rejected and not included in a second run of analysis. Furthermore the second run analysis of first layer as shows in Table 6 , indicates that the multiple correlation coefficient $(R)$ which using all the predictors simultaneously is 0.821 and R-square is 0.673 which means that 67.3 percent of the variance in a social life can be predicted from the factors of social-entrepreneurship. Meanwhile, it is noted that adjusted R-square (0.668) is lower than the R-square (0.673) which is related to the number of variables in the study. Furthermore, Table 7 (ANOVA) describes the $F$ values is equal to 134.595 and its statistically significant value equal to 0.000 .

Table 6. R-Square

\begin{tabular}{|ccccc|}
\hline Model & R & R-Square & Adjusted R-Square & Std. Error of Estimate \\
\hline 1 & $0.821^{\mathrm{a}}$ & 0.673 & 0.668 & 0.33358 \\
\hline
\end{tabular}

a. Predictors: (Constant), social economic, non-profit, cooperation, welfare

b. Dependent variable: Quality of life

Table 7. ANOVA

\begin{tabular}{|ccccccc|}
\hline Model & & Sum of Squares & $\mathrm{df}$ & Mean Square & $\mathrm{F}$ & Sig. \\
\hline \multirow{2}{*}{1} & Regression & 59.910 & 4 & 14.978 & 134.595 & $0.000^{\mathrm{b}}$ \\
& Residual & 29.044 & 261 & 0.111 & & \\
& Total & 88.954 & 265 & & & \\
& & & & & & \\
\end{tabular}

a. Dependent variable: Quality of life

b. Predictors: (Constant), social economic, non-profit, cooperation, welfare

According to Table 8 , among 3 independent variables in social-entrepreneurship and intermediary variable (social economic), the factor of social economic $(B=0.313, p=0.000)$ was the main contributor that support the quality of life. The factor of welfare become as the second contributor $(B=0.264, p=0.000)$ in the study. Meanwhile, another 2 attributes which are non-profit $(B=0.172, p=0.004)$ and cooperation $(B=0.157, p=0.010)$ were significantly indicate the relationship of quality of life.

Table 8. Multiple Linear Regressions

\begin{tabular}{ccccccc}
\hline \multirow{2}{*}{ Model } & \multicolumn{2}{c}{ Unstandardized Coefficients } & Standardized Coefficients & t & \multirow{2}{*}{ Sig. } \\
& B & Std. Error & & Beta & & \\
\hline & (Constant) & 0.058 & 0.168 & & 0.347 & 0.729 \\
& Cooperation & 0.166 & 0.065 & 0.172 & 2.578 & 0.010 \\
1 & Non-profit & 0.184 & 0.063 & 0.264 & 2.895 & 0.004 \\
& Welfare & 0.276 & 0.076 & 0.313 & 3.609 & 0.000 \\
& Social economic & 0.339 & 0.077 & & 4.413 & 0.000 \\
\hline
\end{tabular}

a. Dependent variable: Quality of life

\subsection{Relationship of social-entrepreneurship and social economy (second layer)}

Furthermore, the second layer of path-analysis were studied the relation of social-entrepreneurship and social economic which included $\mathrm{H6}, \mathrm{H} 7, \mathrm{H} 8$ and $\mathrm{H} 9$. In term of significance study of each hypothesis, the results indicates that 2 out of 4 
hypotheses are positively significance and accepted which are $\mathrm{H} 8(\mathrm{p}=0.006)$ and $\mathrm{H} 9(\mathrm{p}=0.000)$. Meanwhile, the other 2 hypothesis are not significance and rejected such as H6 $(p=0.169)$ and H7 $(p=0.282)$ as shown in Table 9.

Table 9. Significance of Variables

\begin{tabular}{|c|c|c|c|c|c|c|}
\hline & \multirow{2}{*}{ Model } & \multicolumn{2}{|c|}{ Unstandardized Coefficients } & \multirow{2}{*}{$\begin{array}{c}\text { Standardized Coefficients } \\
\text { Beta }\end{array}$} & \multirow{2}{*}{$\mathrm{t}$} & \multirow{2}{*}{ Sig. } \\
\hline & & B & Std. Error & & & \\
\hline \multirow{5}{*}{1} & (Constant) & 0.305 & 0.139 & & 2.197 & 0.029 \\
\hline & Cooperation & 0.071 & 0.052 & 0.073 & 1.381 & 0.169 \\
\hline & Non-profit & 0.060 & 0.056 & 0.061 & 1.078 & 0.282 \\
\hline & Volunteerism & 0.170 & 0.061 & 0.154 & 2.796 & 0.006 \\
\hline & Welfare & 0.623 & 0.047 & 0.647 & 13.129 & 0.000 \\
\hline
\end{tabular}

a. Dependent variable: Socio-economy

As well as to find out the R-square and beta value for each hypothesis of second layer, the second run analysis of second layer was simulated. The result indicates that the multiple correlation coefficient $(R)$ which using all the predictors simultaneously is 0.855 . The R-square is 0.731 which means that $73.1 \%$ of the variance in a social economic can be predicted from the factors of social-entrepreneurship as shown in Table 10.

Table 10. The $\mathrm{R}^{2}$ of Second Layer

\begin{tabular}{|c|c|c|c|c|}
\hline Model & R & R-Square & Adjusted R-Square & Std. Error of Estimate \\
\hline 1 & $0.855^{a}$ & 0.731 & 0.730 & 0.27768 \\
\hline
\end{tabular}

a. Predictors: (Constant), welfare

b. Dependent variable: Social economic

In the study of second layer of path-analysis, there is only the factor of social change is significantly association with the small business performance $(B=0.329, p=0.008)$. Table 11 displays the result of second layer of the analysis.

Table 11. Beta Value of Second Layer

\begin{tabular}{|c|c|c|c|c|c|c|}
\hline Model & & Unstandardized Coefficients & Standardized Coefficients & $\mathrm{t}$ & Sig. & \\
\hline & & $\mathrm{B}$ & Std. Error & Beta & & \\
\hline 1 & (Constant) & 0.709 & 0.123 & & 5.776 & 0.000 \\
\hline & Welfare & 0.823 & 0.031 & 0.855 & 26.778 & 0.000 \\
\hline
\end{tabular}

a. Dependent variable: Social economic

\subsection{Path model}

As well as in a path-analysis, the significance results of multiple regressions attempt to illustrate the interrelationship of cooperation, social work and non-profit concerning (independent variables) with the social economy (intermediary variable) and quality of life (dependent variable). The analysis was used a path coefficient which applied the standard regressions coefficient to show the direct and indirect effect of independent variables on a dependent variable in the pathmodel. The first run of multiple regression analysis show that the factor of social economy is not become prominent intermediary variable as well as to contribute the quality of life among coastal entrepreneurs in Terengganu. However, the factor of social economy becomes essential for coastal communities whenever to construct the social work toward quality of life.

Figure 1 shows the results of second run of multiple regression analysis that supported the social economy as an intermediary variable of association between social-entrepreneurship and quality of life. About $67.3 \%$ of variance in quality of social life is contributed by the factors of social entrepreneurship (e.g. cooperation, non-profit concerning and welfare) and social economic, whereas another $31.1 \%$ of variance in social economic is contributed by the factor of welfare. In addition, the results indicated that beta value are 0.157 in a relationship of cooperation and quality of social life, 0.172 in a relationship of non-profit concerning and quality of life, 0.264 in a relationship of welfare and quality of life, and 0.855 in a relationship of welfare and social economic. Therefore, the factor of social economic is not really important in developing the quality of social life among coastal entrepreneurs in Terengganu. In conclusion, it visualizes the result 
of significance relationship between factors of social-entrepreneurship (cooperation, non-profit and welfare), social economic and quality of life.

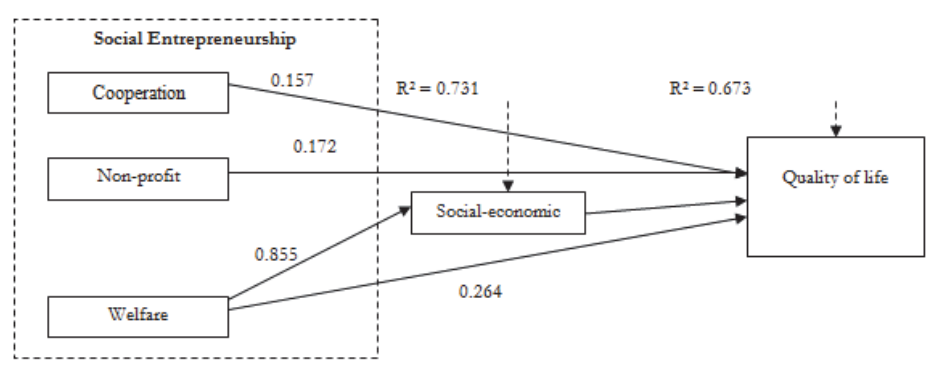

Figure 1. Path-Model of Social Entrepreneurship

\section{Discussion and Conclusion}

The results of the study provide useful recommendations in term of significant relationship between socialentrepreneurship, social economic and quality of life. Additionally, the results also assist to increase the encouragement of coastal communities in constructing cooperation in business, non-profit concerning, volunteerism and welfare. The findings also found that most of coastal communities in Terengganu are concerned toward the important of socialentrepreneurship in building quality of life. Furthermore, the research used path-analysis to analyze 6 variables which are classified either as an independent, intermediary and dependent variable such as cooperation, volunteerism, non-profit concerning and welfare. In order to predict the relationship of indepdent varibales, intermediary and dependent variable, the path analysis was used to measure the alternative path which can be applied in the research. The results indicated that 3 out of 4 indepdenent variables (e.g. cooperation, welfare and non-ptofit concerning) are involved direct effect to the quality of life. Meanwhile, only factor of welfare is involved path through the social economic to the quality of life. Therefore, the factor of social economic becomes prominent as intermediary varibale in relationship of welfare and social life. In general, the finding provide positive results toward $\mathrm{H} 1, \mathrm{H} 2, \mathrm{H} 4, \mathrm{H} 5, \mathrm{H} 6, \mathrm{H} 7$ and $\mathrm{H} 9$ as claimed by Yunus (2011), Zakaria (2011), Yunus (2009), Brooks (2008), Mair and Marti (2006), Zahra et al. (2009), Bygrave and Hofer (1991).

Therefore, it is generally perceived that the factor of social-entrepreneurship assist to develop the factors of quality of life. It can contribute to the execution of coastal communities in Terengganu. As a solution, the study tried to resolve the research questions and hypothesis by constructing a path-model to look the path coefficient between variables. As noted in literature, coastal entrepreneurs in Terengganu also need the strong social-entrepreneurship which are helping their development of social development and become quality of their social life. In summary, the study provided an insight on the perceptions of coastal entrepreneurs which regarding to the business opportunities that have been accommodated by government as well as to increase their income, created level of employment and also create quality of life. Malaysia government has launched the New Economic Policy, National Development Policy and Vision 2020 in objective to establishing prosperous rural and coastal communities with an economy that is fully competitive, dynamic, robust and resilient. Therefore, the outcomes from the research offer a clear picture to the state government in east-coast Malaysia to determine the factors and items that accepted by coastal entrepreneurs in developing their business performance as contributing to the changing of quality of life.

\section{References}

Alvord, S. H., Brown, L. D., \& Letts, C. W. (2004). Social entrepreneurship and societal transformation: An exploratory study. The Journal of Applied Behavioral Science, 40, 260-282.

Ariff, M. R. M., Sharir, M., Ali, I., Majid, M., \& Hussin, H. (2012). Perkembangan perusahaan perikanan di Semenanjung Malaysia: Isu dan persoalan (The development of fishing industry in Peninsula Malaysia: Issues and questions). Journal of Southeast Asian Studies, 16, 265-299.

Barendsen, L., \& Gardner, H. (2004). Is the social entrepreneur a new type of leader? Leader to Leader, 34, 43-50.

Brooks, A. C. (2008). Social entrepreneurship: A modern approach to social value creation. (1st ed.). New Jersey: Prentice Hall.

Bygrave, W. D., \& Hofer, C. W. (1991). Theorizing about entrepreneurship. Entrepreneurship Theory and Practice, 16, $13-22$.

East Coast Economic Region, (2013), ECERDC attracts RM23b in investments for Pahang in 5 years, says menteri besar. [Online] 
Available: http://www.ecerdc.com.my/ecerdc/ (August 9, 2013)

Halim, M. A. S. A., Muda, M. S., Hasan, Z. R. A., \& Salleh, A. M. M. (2014). Coastal communities: Principles of social entrepreneurship in constructing the social life. In 3rd International Conference on Accounting, Business and Economics, 177-192.

Hamzah, R., Isa, K. M., \& Janor, R. M. (2010). Spiritual education development model. Journal of Islamic and Arabic Education, 2, 1-12.

Idris, R. A. (2001). Sosio ekonomi dan pembangunan dalam komuniti nelayan: Satu kajian kes di Kampung Air Tawar, Besut Terengganu. (Bachelor dissertation, Universiti Malaya, 2001).

Light, C. P. (2005). Searching for social entrepreneurs: Who they might be, where they might be found, what they do. In Conference of the Association for Research on Nonprofit and Voluntary Organizations, 17-19.

Mair, J., \& Marti, I. (2006). Social entrepreneurship research: A source of explanation, prediction and same, different, or both? Journal of World Business, 41, 36-44.

Mat, S. H. C., Hussin, F., \& Jali, M. R. M. (2003). Ekonomi Malaysia. Malaysia: PTS Distribution.

Nawang, W. M. Z. W., Ahmad, W., Mamat, I., \& Isa, A. M. M. (2009). Faktor peramal minat belia untuk menjadi nelayan: Satu kajian di mukim Kuala Besut, Terengganu. Sains Humanika, 50, 29-52.

Nunnally, J. C., \& Bernstein, I. H. (1994). Psychometric theory, (3rd ed.). New York: McGraw-Hill.

Othman, R. (2002). Pengurusan personel dan perancangan guna tenaga. (2nd ed.). Kuala Lumpur: Dewan Bahasa dan Pustaka.

Rostam, K. (2005). Transformasi ekonomi dan pembandaran di koridor Kemaman-Dungun, Terengganu: Keterlibatan isi rumah Melayu. Journal Sari, 23, 15-36.

Sa'at, N. H. (2011). Mobiliti sosial dalam kalangan komuniti pesisir pantai: Kajian kes di Kuala Terengganu. Kajian Malaysia, 29, 95-123.

Samsudin, M., Manaf, A. A., \& Shaharuddin, S. (2011). Perkembangan pengangkutan marin sekitar Pantai Timur Tanah Melayu zaman tradisional dan zaman pentadbiran British (The development of marine transport around the east coast of Malaya from the early age to the period of the British administration). Journal of Tropical Marine Ecosystem, 2, 30-42.

Sarif, S. M., Sarwar, S., \& Ismail, Y. (2013). Practice of social entrepreneurship among the Muslim entrepreneurs in Malaysia. MiddleEast Journal of Scientific Research, 14, 1463-1470.

Schumpeter, J. A. (2009). Can capitalism survive? (3rd ed.). HarperCollins Publishers.

Sirgy, M. J., Gao, T., \& Young, R. F. (2008). How does residents' satisfaction with community service influence quality of life (QOL) outcomes? Applied Research Quality Life, 3, 81-105.

Thompson, J. L. (2002). The world of the social entrepreneur. International Journal of Public Sector Management, 15, $412-431$.

Weerawardena, J., \& Mort, G. S. (2006). Investigating social entrepreneurship: A multidimensional model. Journal of World Business, 41, 21-35.

Wright, S. (1960). The treatment of reciprocal interaction, with of without log in path analysis. Journal of Biometrics, 16, 423-441.

Young, D. R. (1986). Entrepreneurship and the behaviour of non-profit organization: Elements of a theory. In S. R. Ackerman (Eds.), The economics of non-profit institutions: Studies in structure and policy (pp. 161-184). New York: Oxford University Press.

Yunus, M. (2009). Creating a world without poverty: Social business and the future of capitalism. New York: PublicAffairs.

Yunus, M. (2011). Building social business: The new kind of capitalism that serves humanity's most pressing needs. New York: PublicAffairs.

Zahra, S. A., Gedajlovic, E., Neubaum, D. O., \& Shulman, J. M. (2009). A typology of social entrepreneurs: Motives, search processes and ethical challenges. Journal of Business Venturing, 24, 519-532.

Zakaria, F. (2011). Social enterprise in Malaysia: The UMK experience. In Developments in Solidarity Economy in Asia, 123-138. 